\title{
Aggressive local treatments may prolong survival but do not have curative intent
}

\author{
Paul H. Sugarbaker ${ }^{1}$, Kurt Van der Speeten ${ }^{2}$ \\ ${ }^{1}$ MedStar Washington Hospital Center, Washington, DC, USA; ${ }^{2}$ Department of Surgery, Hospital Oost-Limburg, Genk, Belgium \\ Correspondence to: Paul H. Sugarbaker, MD. MedStar Washington Hospital Center, Washington, DC, USA. Email: Paul.Sugarbaker@outlook.com; \\ Kurt Van der Speeten. Department of Surgery, Hospital Oost-Limburg, Genk, Belgium. Email: Kurt.Vanderspeeten@zol.be. \\ Comment on: Boerner T, Piso P. A narrative review of intraperitoneal chemotherapy and cytoreductive surgery (CRS) for peritoneal metastases in \\ gastric cancer. J Gastrointest Oncol 2021;12:S59-67.
}

Submitted Dec 16, 2020. Accepted for publication Mar 16, 2021.

doi: 10.21037/jgo-2020-12

View this article at: http://dx.doi.org/10.21037/jgo-2020-12

Boerner and Piso provided the reader with a well-balanced and comprehensive review of the treatment options for gastric cancer with PM (1). They remind us of the devastation caused by peritoneal disease in that $46 \%$ of patients with recurrent cancer show this pattern of surgical treatment failure. They cite their own data in which 38 patients treated by gastrectomy, cytoreductive surgery plus HIPEC showed a median survival of 17.2 months versus 11 months for surgery and systemic chemotherapy in the absence of HIPEC $(\mathrm{P}=0.004)$. Their HIPEC was cisplatin at $75 \mathrm{mg} / \mathrm{m}^{2}$ plus doxorubicin $15 \mathrm{mg} / \mathrm{m}^{2}$ for 90 minutes at $42{ }^{\circ} \mathrm{C}$. Emphasis on patient selection $(\mathrm{PCI}<10)$ so that a complete cytoreduction was probable was documented by their data. Their concept is that intraperitoneal treatment (HIPEC, EPIC, NIPEC) delays the progression of peritoneal metastases and thereby prolongs survival. As we look for a "take home message", these authors are telling us that the longer an aggressive local-regional treatment plan can be continued, the longer the return of PM can be suppressed. These authors remind the reader that these treatments do not eradicate the peritoneal disease in the vast majority of patients. Despite cytoreductive surgery and aggressive intraperitoneal chemotherapy, nearly all patients develop local peritoneal recurrence. These treatments may prolong survival but are not curative.

\section{Acknowledgments}

Funding: None.

\section{Footnote}

Provenance and Peer Review: This article was commissioned by the editorial office, Fournal of Gastrointestinal Oncology for the focused issue "Intraperitoneal Chemotherapy for Peritoneal Metastases: HIPEC, EPIC, NIPEC, PIPAC and More". The article did not undergo external peer review.

Conflicts of Interest: Both authors have completed the ICMJE uniform disclosure form (available at http:// dx.doi.org/10.21037/jgo-2020-12). The focused issue was sponsored by the Peritoneal Surface Oncology Group International (PSOGI). Drs. PHS and KVDS served as the unpaid Guest Editors of the focused issue. The authors have no other conflicts of interest to declare.

Ethical Statement: The authors are accountable for all aspects of the work in ensuring that questions related to the accuracy or integrity of any part of the work are appropriately investigated and resolved. 
Open Access Statement: This is an Open Access article distributed in accordance with the Creative Commons Attribution-NonCommercial-NoDerivs 4.0 International License (CC BY-NC-ND 4.0), which permits the noncommercial replication and distribution of the article with the strict proviso that no changes or edits are made and the original work is properly cited (including links to both the formal publication through the relevant DOI and the license).

Cite this article as: Sugarbaker PH, Van der Speeten K. Aggressive local treatments may prolong survival but do not have curative intent. J Gastrointest Oncol 2021;12(Suppl 1): S68-S69. doi: 10.21037/jgo-2020-12
See: https://creativecommons.org/licenses/by-nc-nd/4.0/.

\section{References}

1. Boerner T, Piso P. A narrative review of intraperitoneal chemotherapy and cytoreductive surgery (CRS) for peritoneal metastases in gastric cancer. J Gastrointest Oncol 2021;12:S59-67. 